\title{
May $1965^{\prime}$
}

Vol. LXXIX No. 5

\section{The Journal of \\ Laryngology and Otology \\ EDITED BY \\ G. H. BATEMAN \\ ASSISTANT EDITOR \\ LIONEL TAYLOR}

\section{Contents}

/ The ETIOLOGY OF CHRONIC RHINITIS AND Sinusitis IN CHILDREN ? - . .

$\checkmark$ THE NATURAL History aNd THERAPy of Nasal Bleeding Productng Geriatric Problems

T. G. WILSON

E. SZABO

$\checkmark$ Pathogenesis of Cysts and CRypts in the NASOPHARYNX

M. Y. ALI

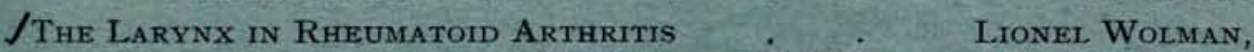

Christopher $\dot{S}$. DARKe, and Austen Young

$\checkmark$ DECANNULATION AFTER TRACHEOSTOMY IN INFANTS AND YOUNG CHILDREN

ROLAND S. LEWIS and HAROLD LUDMAN

JOCCULt CANDIDIASIS IN THE PATERSON BROWNKELLY SYNDROME.

O. H. SHAHEEN

Clinical Records-

- Five Cases of Bilateral Branchial fistulae in Three Generations of a Family .

- A Case of Bilateral PNeumothorax after TRACHEOSTOMY . . . . .

2 FAtal HamorRhage from the INNOMtNate ARTERY AFTER TRACHEOTOMY

P. M. Binns and O. C. LORD

S. D. PARTKH

L. VERESS and

I. ROMHÁNYI

$\checkmark$ THE EFFECT OF TEMPORARY AUTONOMIC BLOCK ON THE SO-CALLED Allergic CONDITIONS of the Nasal Mucosa, "A Preliminary REPORT" . . A. EL-BARBARY and K. M. Botros

1 Eosinophilic Granuloma N. H, MAHINDRAKAR GENERAL Notes

London

\section{Headley Brothers}

\section{Kingsway $\mathrm{WC}_{2}$}




\title{
The Journal of
}

Laryngology and Otology

(Founden in 1887 by MORELL MACKENZIE and Norris WOLFENDEN)

\author{
EDITED BY \\ G. H. BATEMAN
}

ASSISTANT EDITOR

LIONEL TAYLOR

1. Original articles which have not been published elsewhere are invited and should be sent to the Editor. They are considered for publication on the understanding that they are contributed to this Journal solely. Reproduction elsewhere, in whole or in part, is not permitted without the previous written consent of the Author and Editor and the customary acknowledgment must be made.

2. Manuscripts should be typewritten, on one side only of the paper, and well spaced. Captions to illustrations should be typed on a separate sheet and sent at the same time as original photographs, etc.

The Harvard system of recording references should be used, e.g. Grean, C., and Brown, D. (1951) J. Laryng., 65, 33. Abbreviations of Journals should follow the style recommended in World Medical Periodicals, published by World Health Organization, 1952 .

It is most important that authors should verify personally the accuracy of every reference before submitting a paper for publication.

3. Galley proofs and engraver's proofs of illustrations are sent to the author. Corrections, which should be kept to a minimum, must be clearly marked, and no extra matter added. Proofs should be returned within's days.

4. Illustration blocks are provided free up to the limit of fio per article; beyond this authors are expected to pay half the cost. Coloured illustrations will be charged in full to authors.

Blocks will normally be held by the Printers for three years after which they will be destroyed. Any author who has borne a part of the cost of his blocks is entitled to have these returned to him, but a request for this must be sent within three years of the appearance of the article, to HRADLEY BROTHERs, IOO Kingsway, London, $\mathrm{WC}_{2}$.

5. Orders for reprints must be sent when returning galley proofs, and for this purpose special forms are supplied.

6. Authors of original communications on Oto-Laryngology in other journals are invited to send a copy, or two reprints, to the Journal of Laryngology. If they are willing, at the same time, to submit their own abstract (in English, French, Italian, or German) it will be welcomed.

7. Editorial communications may be addressed to THE Enrror, Journal of Laryingology, c/o Headlex Brothers, to9 Kingsway, London, $\mathrm{WC}_{2}$.

8. The annual subscription is five guineas sterling (U.S.A. \$15) post free, and payable in advance.

9. Single copies will be on sale at 125 . 6d. each; copies of parts up to Vol. LXIII which are available may be purchased at $7 \mathrm{~s}$. $6 \mathrm{~d}$. each.

ro. All subscriptions, advertising and business communications should be sent to the publishers, Headlex Brothers, 109 Kingsway, London, WC2.

\section{United Siales of America}

Orders for this Journal may be sent through local booksellers, or to Stechert-HAfNER, INC., 31-33 East roth Street, New York, or direct to the publishers, Hradley Brothers, 109 Knngsway, LONDON, WC2, England. c Journal of Laryngology and Otology, 1965 


\section{CONTENTS}

PAGE

The Etiology of Chronic Rhinitis and Sincsitis in Childrex.

T. G. Wilson (Dublin) . . . . . . . 365

The Natural History and Therapy of Nasal Bleeding Producing Geriatric Problems. E. Szabo (Hatvan, Hungary) . . . . . . . . . . 384

Pathogenesis of Cysts and Crypts in the Nasopharyny. M. Y. Ali (Singapore) . . . . . . . . $39 \mathrm{I}$

The Laryex in Rheumatoid Arthritis. Lionel Wolman, Christopher S. Darke, and Austen Young (Sheffield) . . . 403

Decaxulation after Tracheostomy in Infants and Young Childiken. Roland S. Lewis and Harold Ludman (London) 435

Occult Candidiasis in the Paterson Brown-Kelly Syndrome. O. H. Shaheen (London) . . . . . . . 442

\section{Clinical Records-}

Five Cases of Bilateral Branchial fistulae in Three Generations of a Family. P. M. Binns and O. C. Lord (Leeds)

A Case of Bilateral Pneumothorax after Tracheostomy.

S. D. Parikh (Doncaster)

Fatal Hemorrhage from the Innominate Artery after Tracheotomy. L. Veress and I. Romhányi (Szeged, Hungary)

The Effect of Temporary Autonomic Block on the So-Called Allergic Conditions of the Nasal Mucosa, "A Preliminary Report", A. El-Barbary and K. M. Botros (Cairo)

Eosinophilic Granuloma. N. H. Mahindrakar (London) . 468 


\section{The Hallpike}

\section{Operating}

\section{Headlamp}

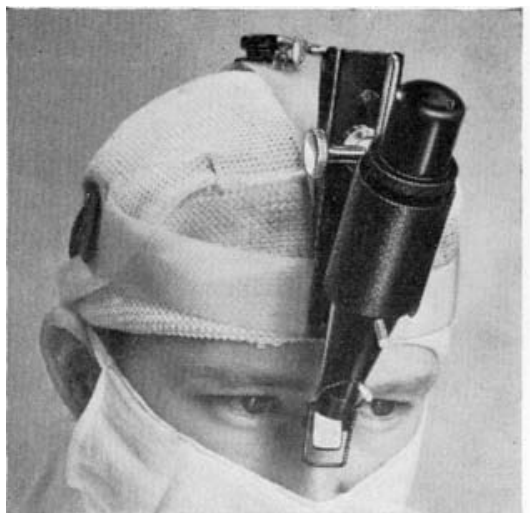

This Operating Headlamp has been based on designs and experimental constructions put at our disposal by Mr. C. S. Hallpike, F.R.C.S., F.R.S., of the Otological Research Unit, Medical Research Council, at the National Hospital, Queen Square:

Its lightweight optical system incorporates a heat absorbing filter and projects, at a convenient working distance, a brilliant homogeneous circle of light of $65 \mathrm{~mm}$. diameter. This may be reduced to $12 \mathrm{~mm}$. by means of a built-in iris diaphragm.

Location of the reflector between the surgeon's eyes ensures that his visual axes lie very close to the light beam, thus providing good optical penetration when working in small narrow-neck cavities.

Convenient screw adjustment for fibre/polythene headband.

Adjustable "over-band" for increased comfort during long operations.

Fully adjustable support strut for maximum rigidity of optical system.

Convenient finger grips for removal of headlamp.

Vertical and angular adjustment of lamp unit, with positive locking action.

- Pre-centred, compact filament, $6 \mathrm{v}$. 18 watt lamp.

Iris diaphragm control, with removable sterilizable sleeve.

Control knob, with sterilizable sleeve, for adjustment of mirror angle and lateral rotation of lamp.

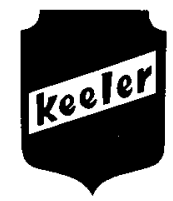

KEE LER

21-27 MARYLEBONE LANE WIGMORE STREET

LONDON, W.I

TELEPHONE: WELBECK 8512

Please mention The Journal of Laryngology and Otology when replying to advertisements 


\section{WHEN A HEARING AID IS RECOMMENDED ONLY AMPLIVOX OFFERS THIS HEARING AID SERVICE}

The design and manufacture of a complete range with individual fitting facilities.

Best of other makes in addition to Amplivox aids-Amplivox hearing aids are ONLY available from Amplivox.

Highest degree of training of any hearing aid organisation.

Master Hearing Aid evaluations.

Expert follow-up and rehabilitation advice.

15 branch offices with while-you-wait service.

FOR YOUR PATIENTS' GREATEST SATISFACTION SPECIFY AMPLIVOX

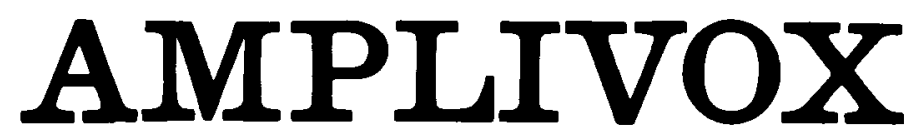

World's most experienced and complete hearing service
AMPLIVOX HEARING ADVISORY SERVICE
80 NEW BOND STREET
LONDON, W.1

Please mention The Journal of Lary'ngology and Otology when replying to advertisements 


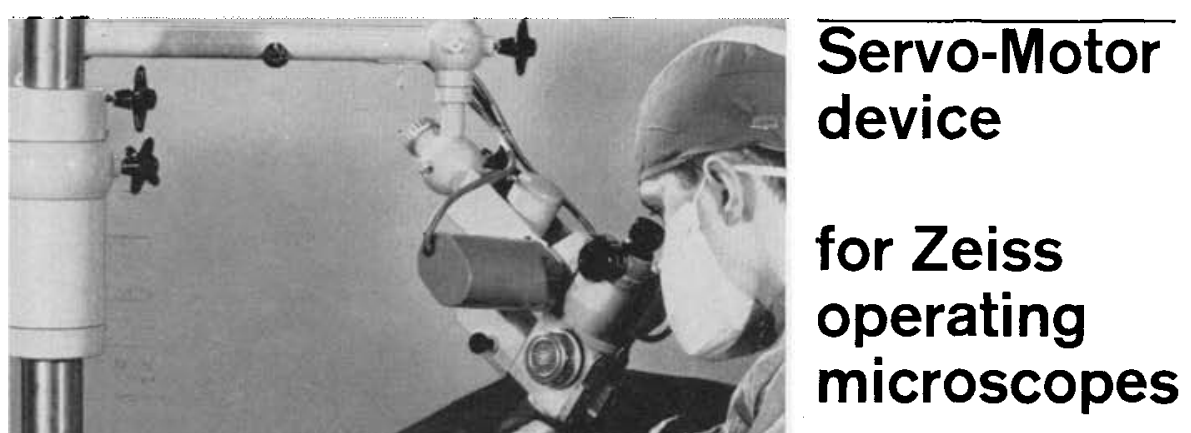

Simply by pressing a foot control the microscope can be focused either upwards or downwards leaving both hands free for manipulation purposes.

Full details

from sole suppliers

Degenhardt \& Co Ltd Carl Zeiss House 20/22 Mortimer Street London W1 Langham 6097 (9 lines)
Scottish enquiries to

Degenhardt \& Co

(Scotland) Ltd

22 Burnbank Gardens Glasgow NW Douglas 0520

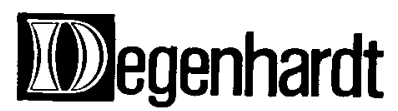

Please mention The Journal of Laryngology and Otology when replying to advertisements 


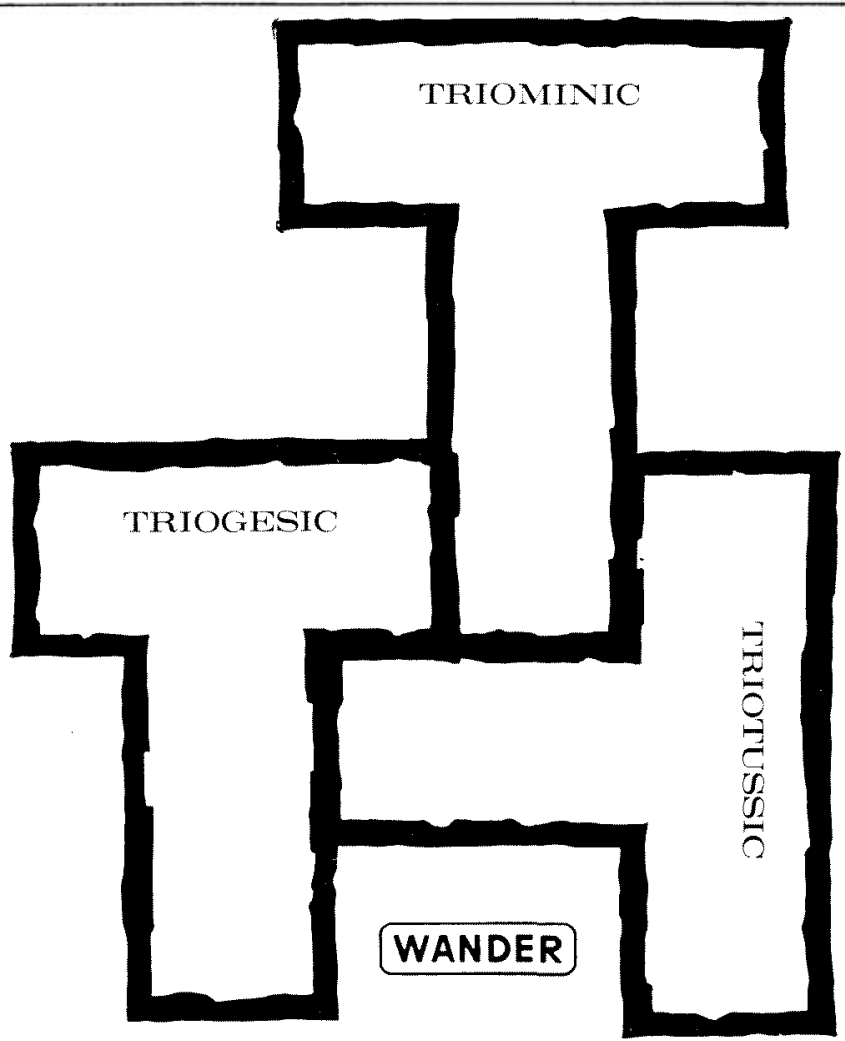

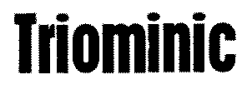

for oral relief of rhinorrhoea and nasal congestion
Formula per

Timed-Release Tablet

Phenylpropanolamine-HCI $50 \mathrm{mg}$.

Mepyramine maleate B.P. $25 \mathrm{mg}$.

Pheniramine maleate $\quad 25 \mathrm{mg}$.

Part 1 S7
Formula per $4 \mathrm{ml}$. Syrup

Phenylpropanolamine- $\mathrm{HCl} 12.5 \mathrm{mg}$. Mepyramine maleate B.P. $6.25 \mathrm{mg}$.

Pheniramine maleate $\quad 6.25 \mathrm{mg}$.

[1 teaspoonful $(4 \mathrm{ml})=\frac{1}{4}$ Tablet] Part 1 S7

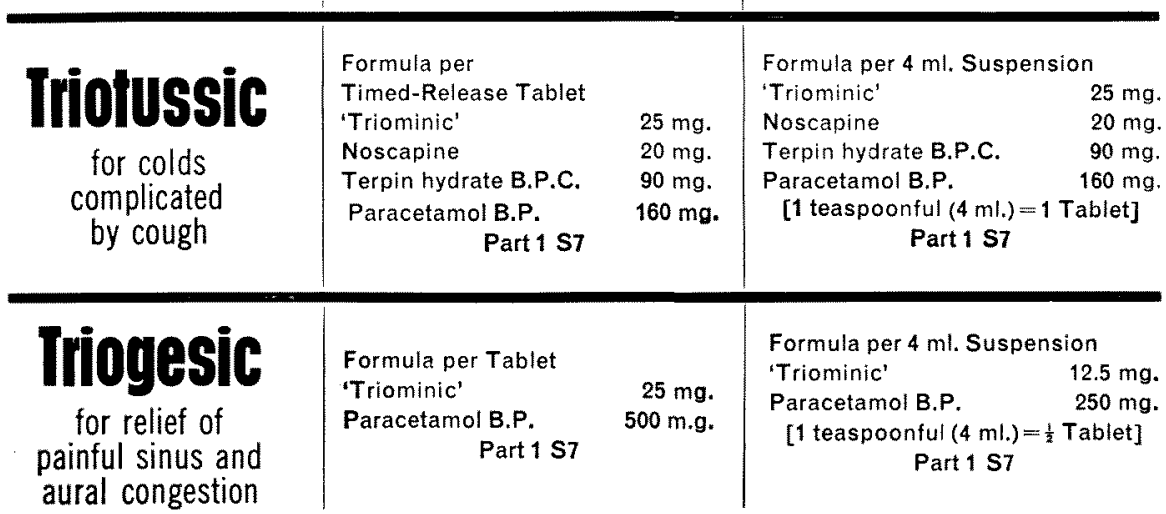

Literature and samples gladly sent on request

M43IA

A. WANDER LIMITED - 42 UPPER GROSVENOR ST * LONDON W. 1

Please mention The Journal of Larngology and Otology when replying to advertisements 


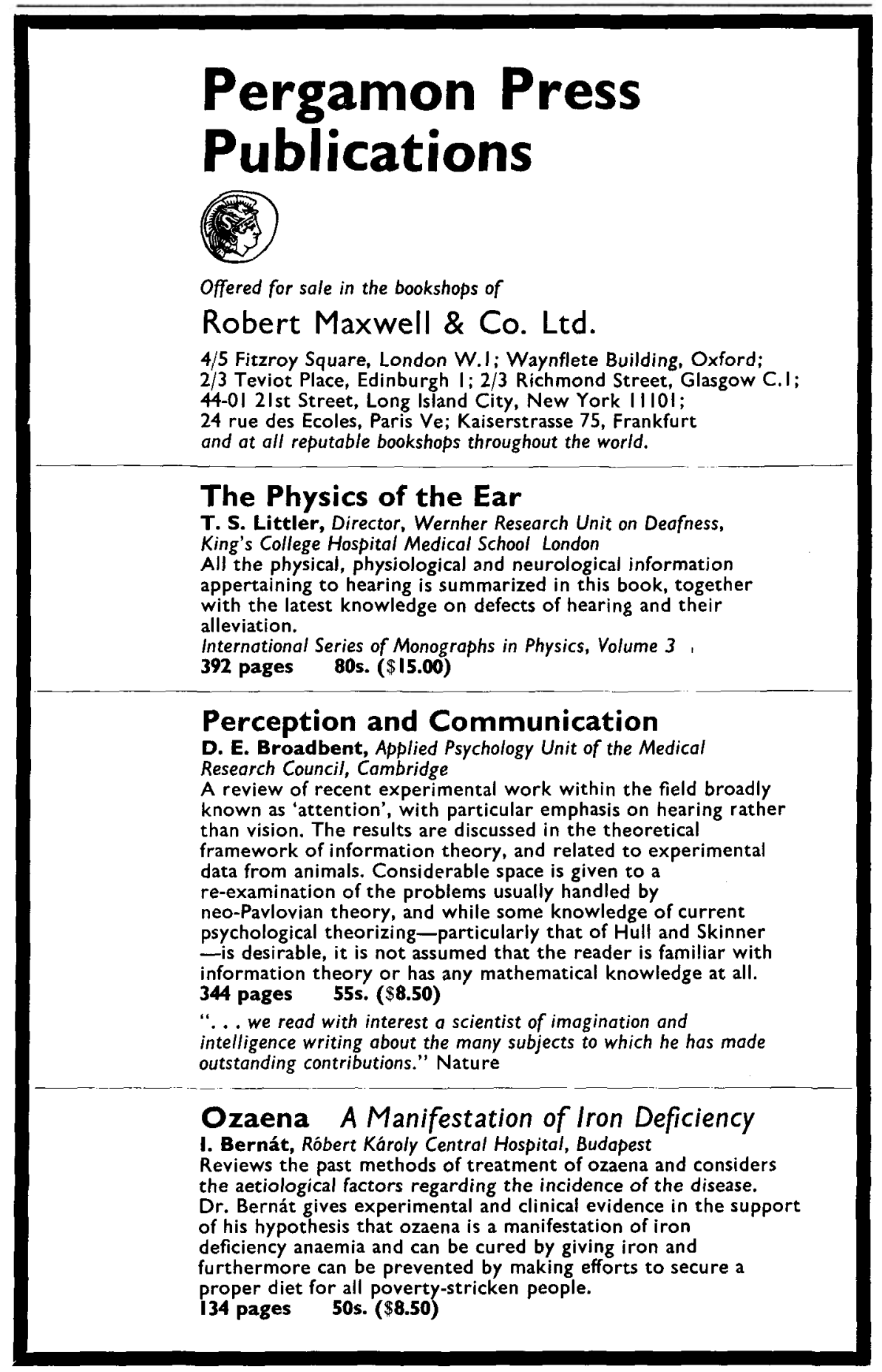

Please mention The Journal of Laryngology and Otology when replying to advertisements 


\section{When}

the patient

needs a

hearing aid-

whom do

you recommend?

\section{INGRAMS, of course,}

the firm with the different makes

to choose from.

INGRAMS, 2 Shepherd Street, London, W.1 


\title{
Atlas der Ohren-, Nasen- und Halskrankheiten
}

\author{
sowie deren Grenzgebiete
}

Von Prof. Dr. med. habil. Dr. med. dent. Isolde Kaiser-Meinhardt, Direktor der Klinik und Poliklinik für Hals-Nasen-Ohrenkrankheiten der Humboldt-Universität (Charité), Berlin. 315 Seiten, 476 größtenteils farb. Abbildungen in 559 Einzeldarstellungen. $18,7 \times 27 \mathrm{~cm}$. 1965. Leinen 164.- MDN.

Der Atlas zeichnet sich dadurch aus, daß er sich vorwiegend auf Originalaufnahmen stützt, also der Auffassung maßgeblicher Wissenschaftler entgegenkommt, die zeichnerischen Darstellungen in Atlanten zugunsten der Originalaufnahmen zurücktreten zu lassen.-Mit dieser Methode wird dem Grundsatz der Praxisnähe weitgehend entsprochen.

Aus einer Fülle von Material hat die Autorin das Wichtigste und Instruktivste systematisch ausgewählt und mit entsprechenden textlichen Erläuterungen $\mathrm{zu}$ einem Atlas zusammengestellt, der modernsten Anforderungen gerecht wird. Die Auswahl wurde so getroffen, daß neben den häufigeren Krankheitserscheinungen auch seltener vorkommende in ihren verschiedenen Stadien dargestellt und erläutert werden. Der Text zu den Abbildungen konzentriert sich vorwiegend auf Anamnese, Verlauf und Behandlung originaler Krankengeschichten, aus denen nur das Wesentliche (z. Teil auch die Ätiologie) gebracht wird. Der Atlas soll der Praxis und dem Studium dienen. Das umfangreiche Vergleichsmaterial wird dazu beitragen, schneller und sicherer zu diagnostizieren.

Bestellen Sie bitte bei Ihrem Buchhändler

\section{VEB GEORG THIEME LEIPZIG}

Please mention The Journal of Laryngology and Otology when replying to advertisements 


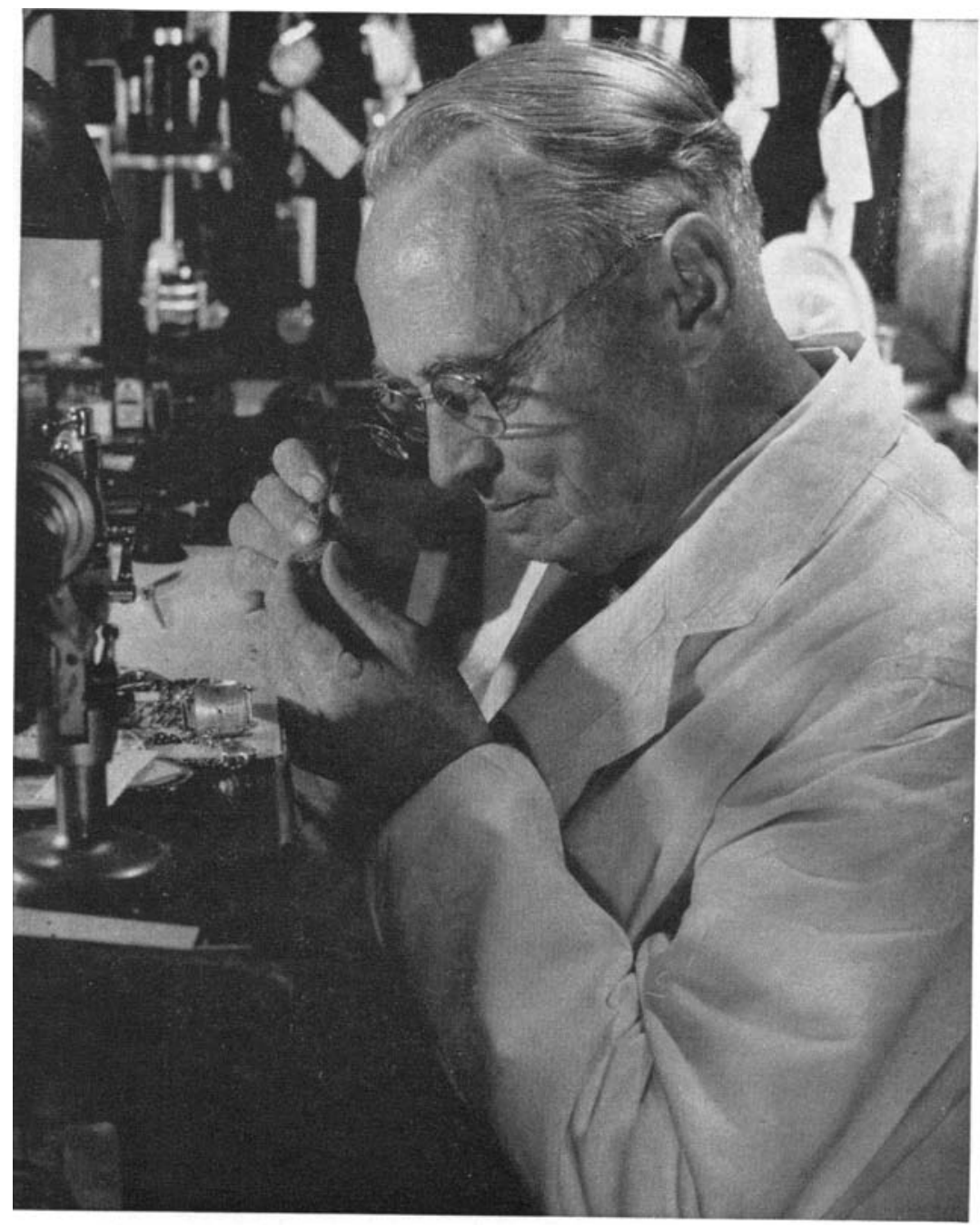

when the patient must remain alert

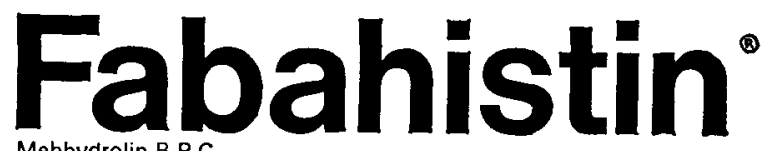

Mebhydrolin B.P.C.

\section{the non-sedating antihistamine}

Children: 1-4 tablets daily Adults : 2-6 tablets daily

\section{(1) Registered trade mark of BAYER GERMANY \\ (4) FBA U.K. Subsidiary FBA PHARMACEUTICALS LTD, Haywards Heath, Sussex}

Please mention The Journal of Lary'ngology and Otology when replying to advertisements 


\section{THE LARYNGOSCOPE}

A Monthly Journal

devoted to the disease of

EAR, NOSE AND THROAT

Official organ for the American Laryngological Rhinological and Otological Society

Price $\$ 18.00$ per year Canada $\$ 19.00$ per year Foreign $\$ 19.00$ per year

ESTABLISHED 1896

TheOdORE E. WALSh, M.D. EDITOR

\section{SOUTH EUCLID AVENUE} SAINT LOUIS MO. 63110.

For advertisement space in this Journal apply to

\section{HEADLEY BROTHERS LTD.}

109 Kingsway London WC2

Please mention The Journal of Laryngology and Otology when replying to advertisements 


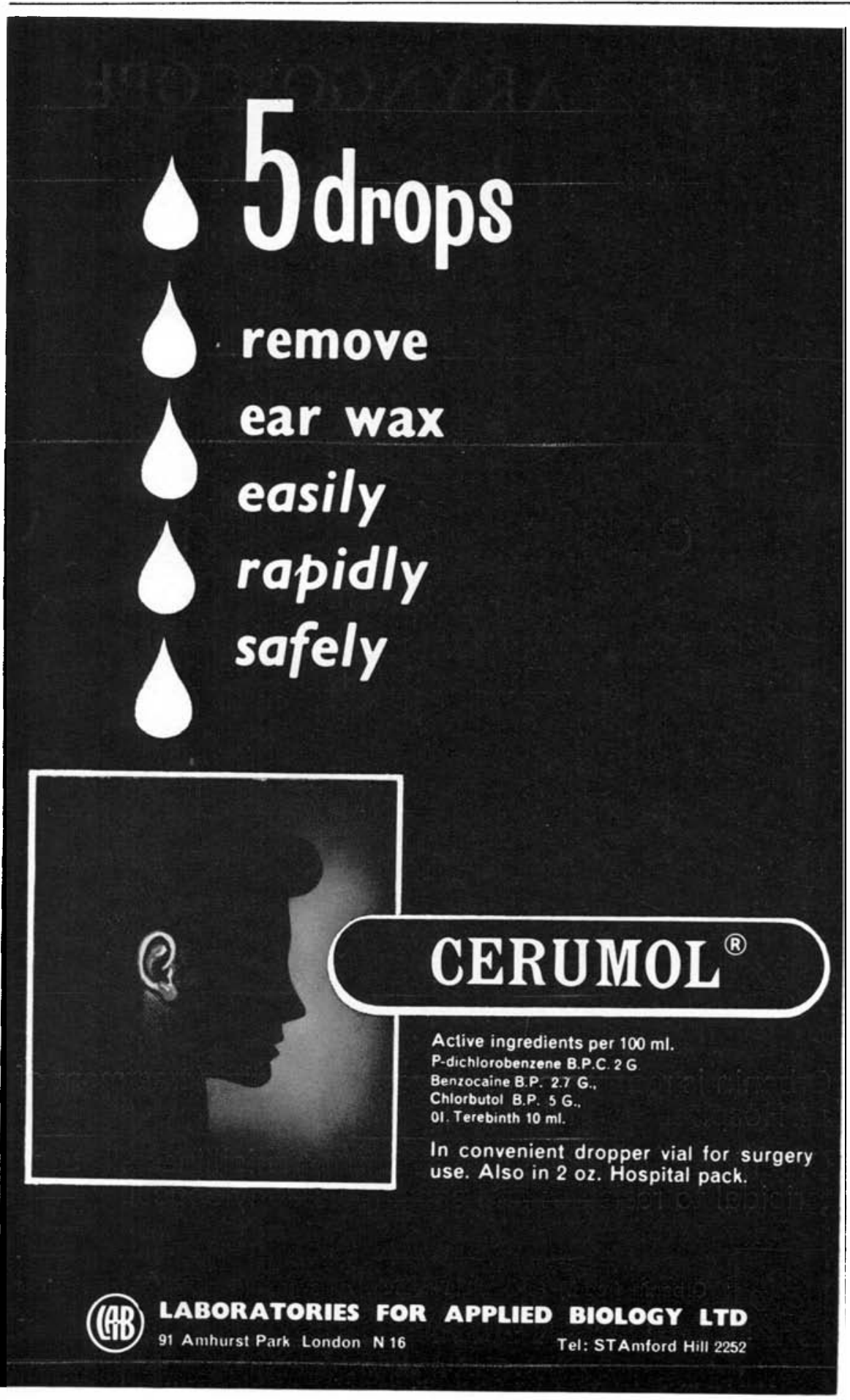

Please mention The Journal of Laryngology and Otology when replying to advertisements 


\section{Staphylococci}
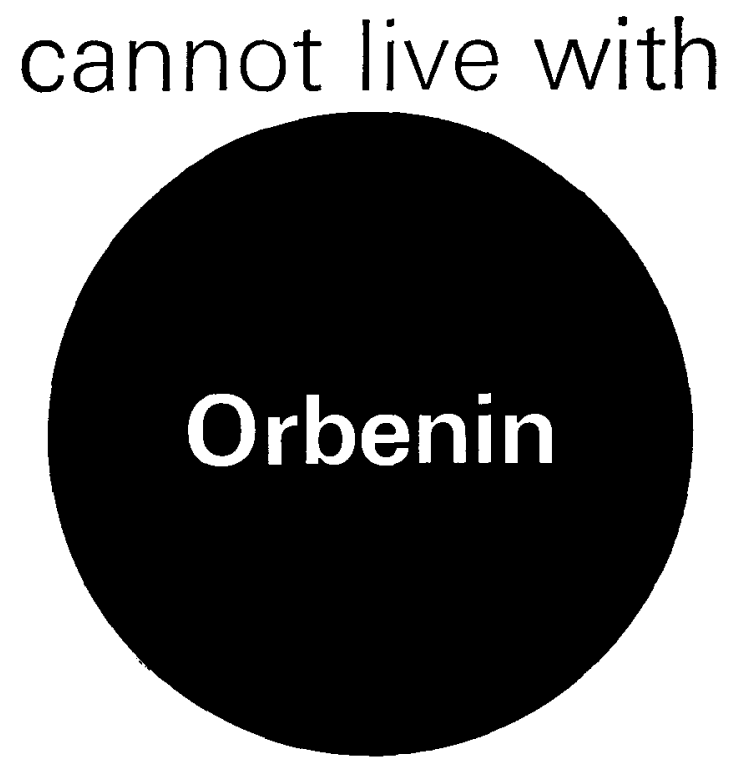

Orbenin is recommended for the immediate treatment of all Hospital Staphylococcal infections

Orbenin, an oral penicillin stable to penicillinase, is bactericidal to resistant and sensitive staphylococci 
ONLY AMPLIVOX provides a complete audiometric service!

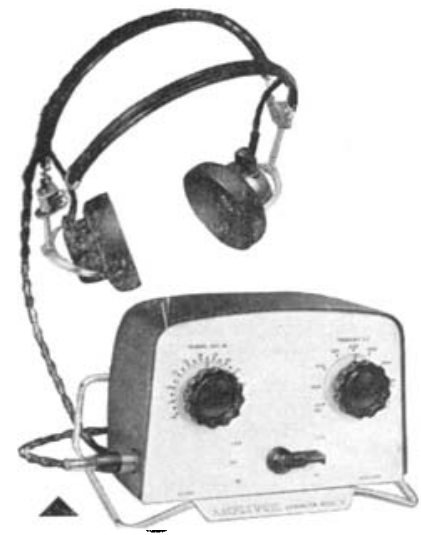

Transistor Audiometers

with air conduction or air and bone conduction with masking, for hospitals, schools, consulting rooms, industrial medical departments, screening programmes, etc.

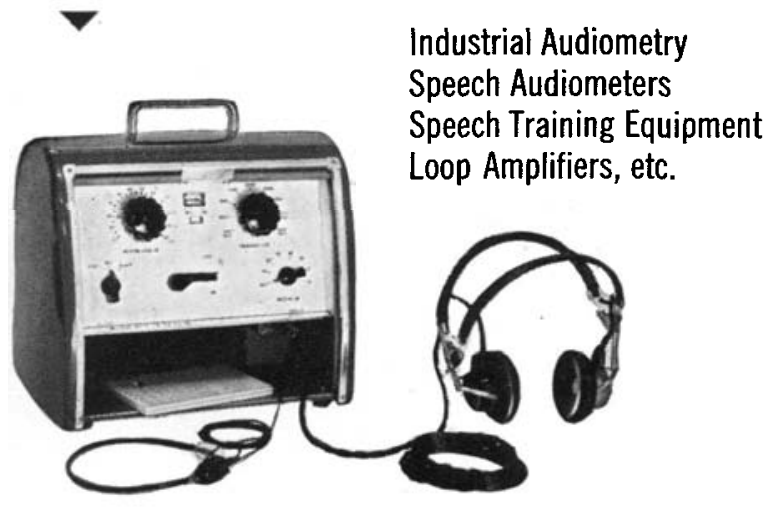

P L U S An efficient and speedy calibration service please write for technical Iiterature to meet your needs

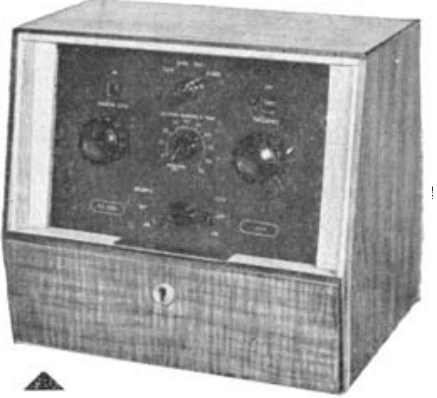

Clinical Audiometers

with narrow band masking for the highest accuracy and extended resolution.

\section{Audiometer Booths}

for ideal testing conditions in hospitals, clinics, factories. Standard and special sizes available.
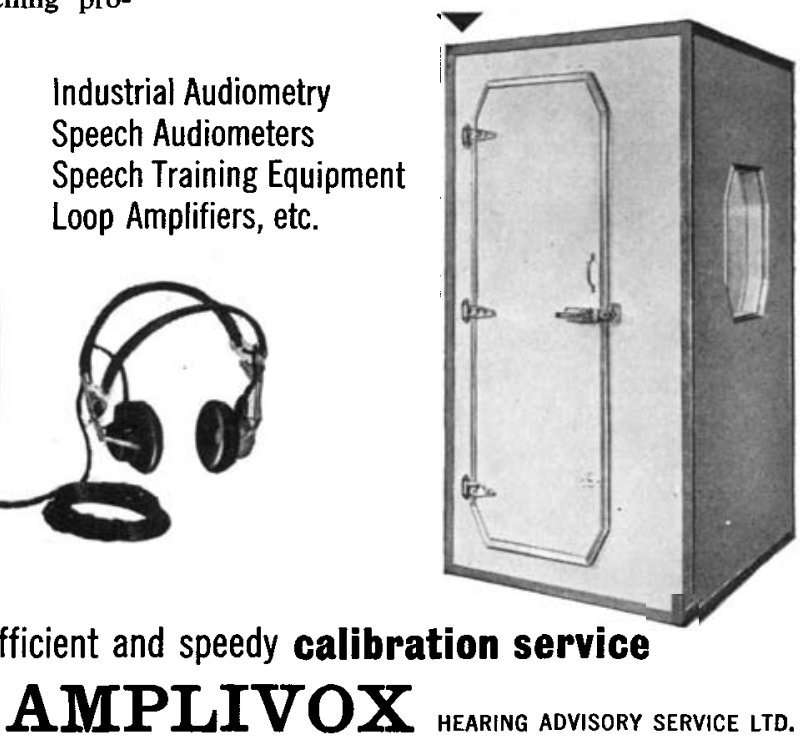

HEARING ADVISORY SERVICE LTD.

80 New Bond Street, London, W.1. Tel: HYDe Park 9888 

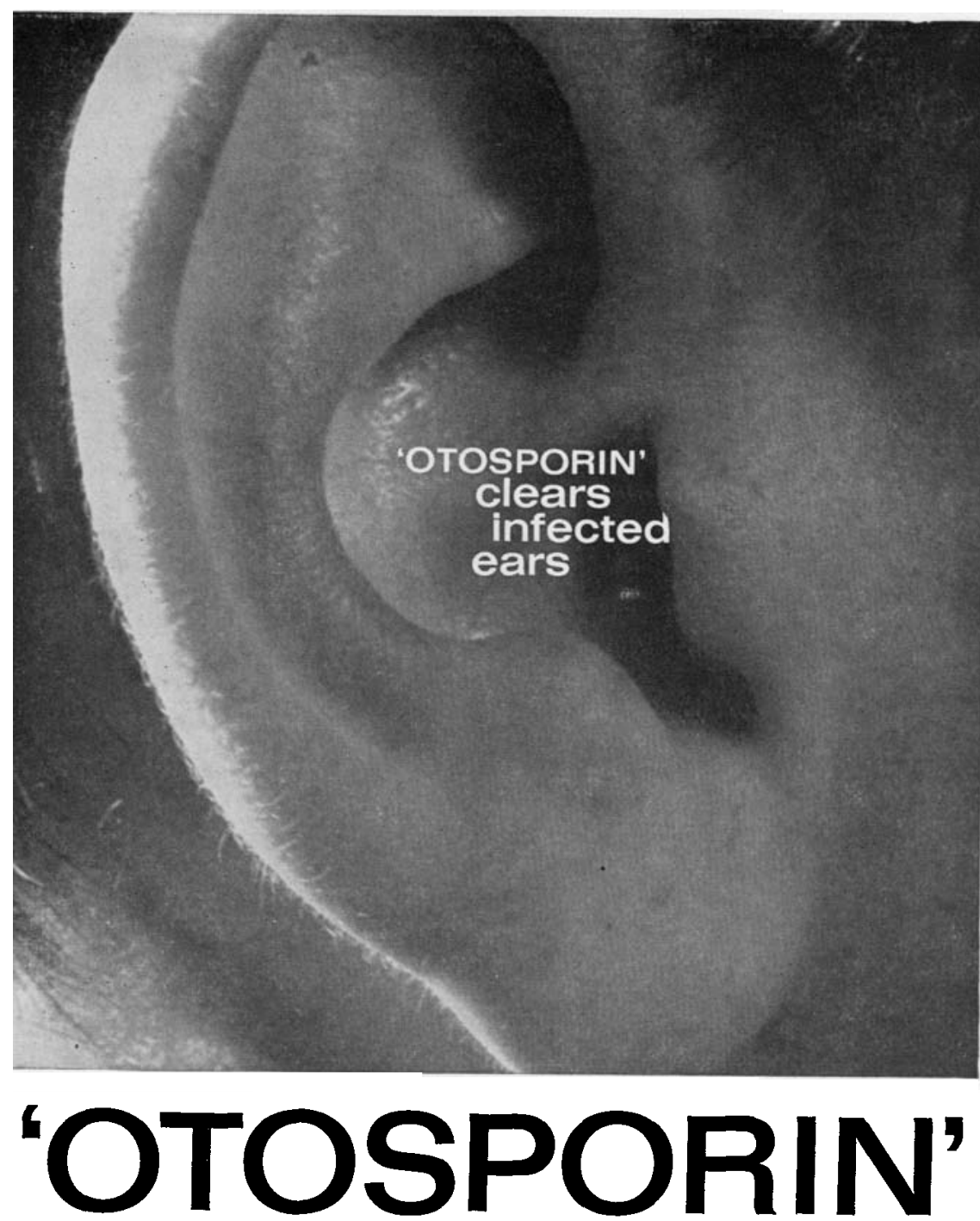

The modern method of treatment in otitis externa, chronic suppurative otitis media, and infected mastoid cavities, is 'Otosporin' Drops. 'Otosporin' is an aqueous suspension containing neomycin and polymyxin B which are together effective against practically all the bacteria found in ear infections. In addition, it contains hydrocortisone to reduce inflammation and swelling, thereby providing easier access for the antibiotics.

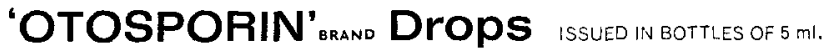

BurRoughs WELLCOME \& CO. (THE WELLCOME FOUNDATION LTD.) LONDON

Please mention The Iournal of Laryngology and Otology when replying to advertisements 